with the various forms of true deer, that the new stag from Amoorland is exceedingly like the Wapiti. The resemblance indeed of the two animals is so close that except for the character of the horns it would be exceedingly difficult to distinguish them. But so far as can be ascertained from an examination of the present specimens, which is now believed to be nearly fcur years old, and from the particulars given of other horns by Dr. Bolau in his description of the present animal, ${ }^{1}$ Liihdorf's deer, as regards the character of its antlers, more nearly resembles our red deer than its American ally.

The discovery of a deer so closely allied to the Wapiti in Eastern Asia is a fact of special interest in geographical distribution. Taken in connection with other similar phenomena which have lately come to light, it tends to show very evidently that Northern America owes its many resemblances to the Palæarctic fauna, not to any former land connection between Europe and North America, as was formerly supposed by the advocates of the fabulous "Atlantis," but to a bygone extension of land between Eastern Asia and Western America. By some such passage there can be little doubt that the ancestors of the Wapiti, the American Bears, the Mountain Goat, and the Rocky Mountain Sheep found their way into the New World, to the more original fauna of which they have no sort of relationship.

\section{METEOROLOGY IN MEXICO"}

$\mathrm{I}_{\text {Mexico, on a high plateau }}^{\mathrm{HE}}$ between two continents and two vast oceans, renders the investigation of its meteorology peculiarly interesting. It is now more than four years since this problem was begun to be worked out with no little ability by the lNexican meteorologists, and, when the resources of the country are taken into account, with a spirit and liberality deserving of every commendation. This praise will not appear overstrained when we say that we have now before us for the city of Mexico a statement of the pressure, temperature, humidity, clouds, rainfall, direction and velocity of the wind, ozone, and other miscellaneous phenomena for every hour of the night as well as of the day, from

March 6, 1877, down to October 16,1880 ; and $c n$ the same sheet, in addition to the above, a daily statement of the chief meteorological elements for some thirty stations situated in various parts of Mexico, and at beights varying from 7 to 8189 feet above the sea. Annual résumés are also before us, that for 1879 having been received some time since.

During I 879 the mean atmospheric pressure at Tlacotalpam, situated near the sea and only i I feet above it, was 29.938 inches, rising to the maximum, 30.075 inches in January, and falling to the minimum $29.85 \mathrm{I}$ inches in August. This seasonal distribution of the pressure holds good till the more elevated stations are reached, when

${ }_{2}$ "Abh. d. Nat. Vereins zu Hamburg, I88०, p. 33.

2 "Datos Meteorologicos: Resumen de lis Observaçiones practicadas en Civil V. Reyes. (Mexico, I880.) "Bole: in del Ministerio (Pcr el Ingeniero la República Mexicana," Tom, ii. iii., iv y. pressure remains pretty constant during the year. This peculiarity becomes strongly marked at Zacatecas, the highest station, 8189 feet above the sea, where the January and July pressures are the same, and the lowest mean, that of March and August, falls only 0.016 inch below the annual mean, and the highest, that of November, rises only $0^{\circ} 024$ inch above it. At all the stations the singular protrusion of a high pressure into the Atlantic and adjoining regions in the height of summer is represented in the means.

Of the greatest possible interest are the curves of the diurnal oscillations of the barometer, deduced from the hourly observations at the central station at Mexico, these curves being quite distinct, so far as we are aware, from the curves of any other intertropical place for which

$$
\text { (n) }
$$

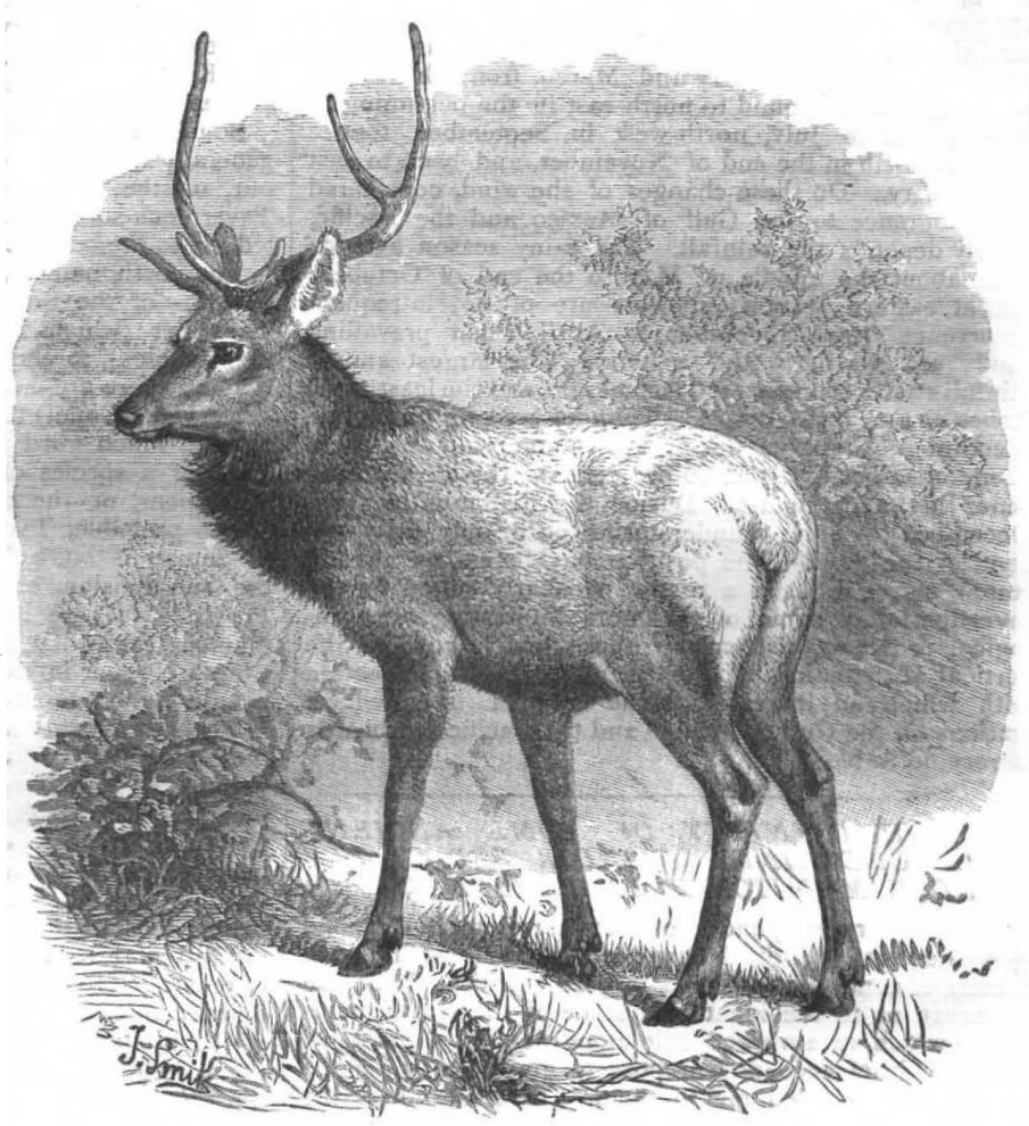

FIG. 7.-The Lühdorf's Deer.

observations exist. The peculiarity lies in this, that while the morning maximum and the afternoon minimum remain large at all seasons, the morning minimum diminishes in amount as the summer advances; and during the strictly summer months it does not even fall so low as the daily mean. Now this is an outstanding peculiarity of the curves of diurnal pressure in the extratropical inland region of the great Europeo-Asiatic continent, and it becomes the more pronounced the more we advance into the interior of that continent. This result, viewed in connection with the other diurnal curves, forms a very valuable contribution to this difficult branch of the science.

The mean temperature for 1879 at Mexico, 7434 feet high, was $59^{\circ} 5$, May being the warmest month, $64^{\circ} \cdot 6$, and December and January the coldest, $55^{\circ} .4$; and these were generally the months of extreme temperature over the 
different districts of Mexico. The period of the year when temperature is highest is also the period when the air is driest, the mean relative humidity of Mexico for April and May for I 878 and I 879 being only 42 . The mean temperature of Tlacotalpam, the lowest station, was $77^{\circ} .5$, and of Zacatecas, the highest from which mean temperatures are published, $6 \mathrm{I}^{\circ} .7$. The difference of the two is thus $15^{\circ} 8$, and as the difference of height is 8178 feet, the fall of temperature with the height is comparatively slow, being only one degree for each 518 feet.

At Mexico during 1879 , out of the 8760 observations made of the wind, 4156 cases were reported as calm, being nearly a half of the whole of the observations. By far the most frequent wind is the north-west, which was observed 1299 times; next follow the north-east, 789 times, and north 636 times; and the least frequent, south, I74 times, and south-west 278 times. As regards direction, the prevailing winds at Mexico were a point to the north of east in February and March, from which they gradually worked round to north-east in the beginning of May, north in July, north-west in September, trence again to north in the end of November, and back to east in February. On these changes of the wind, considered with reference to the Gulf of Mexico and the Pacific, largely depends the rainfall. The rainy season extends from about the middle of May to the end of October; but at eastern stations showers are of not infrequent occurrence from November to April, when prevailing winds are northerly and easterly. The largest annual rainfall was $89^{\circ} 16$ inches at Tlacotalpam, and the least $15^{\circ} 66$ inches at San Luis Potosí. Thunder and lightning are of common occurrence during the summer months, these phenomena occurring on 66 per cent. of the days during June, July, and August. During the five months from December to April thunderstorms occur only on 7 per cent. of the days. The position of Mexico, as already stated, marks it out as a region peculiarly suited for the investigation of some of the more interesting meteorological problems, particularly those which concern the vertical distribution of the phenomena, in connection with which an increase to the number of low-level stations on the Gulf of Mexico and the Pacific sea-boards is very desirable.

ON THE IDENTITY OF SOME ANCIENT DIAMOND MINES IN INDIA, ESPECIALLY THOSE MENTIONED BY TAVERNIER

HAVING recently endeavoured to correlate the diamond deposits of India, I have been surprised to find what a mass of contradiction exists in both Indian and English literature as to the identity of some of the most famous mines which were worked little more than 200 years ago.

In this brief account I propose to give results, not the steps which have led me to them. Tavernier about the middle of the seventeenth century visited and described three diamond-mines, which were named respectively Raolconda in the Carnatic, Gani, called Coulour by the Persians, and Soumelpour on the Gonel River.

Raolconda, Tavernier says, was five days distant from Golconda and eight or nine from Bijapur, and most writers with signal unsuccess have tried to fix it accordingly. But elsewhere Tavernier gives nine stages, aggregating probably 189 miles, on the road from Golconda to Raolconda, so that in the first statement the distances were probably transposed. With these new indications we are led to an old town called Rawdukonda, lat. $15^{\circ} 4 \mathrm{I}^{\prime}$, long. $76^{\circ} 50^{\prime}$. I have not yet succeeded in obtaining any independent testimony of the existence of diamond-mines at this locality, but hope to be able to hear more about it ere long.

Gani, or Coulour, where Tavernier says the Great Mogul diamond was found in the sixteenth century, has been variously located by authors, being supposed by many to be identical with Gani Purtial, on the Kistua River; but I am satisfied from the evidence afforded by old maps that it is to be identified with Kollur, lat. $16^{\circ} 42$ $30^{\prime \prime}$, long. $80^{\circ} 5^{\prime}$, which is also on the Kistna, about twenty. six miles further to the west. Now as to this word Gani, which has been treated of as a proper name, its recurrence in connection with two different localities suggests that it means mine. In fact since $G$ and $K$ are interchangeable letters in some Indian languages we should probably read for Gani Kan-i, or the mine of Purtial or of Kollur.

If, as seems most probable, the Koh-i-nur is identical with the Great Mogul diamond described by Tavernier, and that the great age claimed for it by the Hindus is to be regarded as mythical, then in fact for the first time the identity of the source from whence this famous diamond was obtained may be regarded as settled. Maps of the eighteenth century indicate diamond mines at Gani (i.e. Kan-i) Kollur, though local memory of their former existence appears to have died out.

Soumelpour, on the Gonel River of Tavernier, has generally by recent authors been identified with Sambalpur, on the Mahanadi, in the Central Provinces. But Tavernier's somewhat precise indication of its position has led me to the conclusion that it was situated much further to the north, namely, in the valley of the Koel River, a tributary of the Sone. At about the distance stated by Tavernier (which I calculate to be the equivalent of eighty miles), to the south of the well-known fortress of Rhotas, there are near the banks of the Koel River (i.e. Tavernier's Gonel) the remains of an ancient town called Semah, which word is identical with Semul (the native name of a species of cotton-tree, Bombax Malabaricum), Semulpour, or the town of the Semul, is therefore, it seems probable, Tavernier's Soumelpour. The position of Semah is lat. $23^{\circ} 45^{\prime}$, long. $84^{\circ} 21^{\prime}$; it is included in the sub-division of Palamow, in the Chutia Nagpur Province. There is independent evidence of important diamond mines having existed in a neighbouring part of Chutia Nagpur in the sixteenth century, but there have been none in operation there for many years.

The last locality is Beeragurh, which is mentioned in the Ain-i-Akbari, and also in several other native writings. This is unquestionably identical with the modern Wairagarh in the Chanda district of the Central Provinces, where excavations locally known to have been diamond mines are still to be seen. Wairagarh is in lat. $20^{\circ} 26^{\prime}$, long. $80^{\circ} \mathrm{Io}^{\prime}$. Many allusions which I believe to refer to this locality might be quoted. One of the fifteenth century by Nicolo Conti is of especia interest. $\mathrm{He}$ says that at Albenigaras, fifteen days journey north of Bijapur (Bijengalia), there is a mountain which produces diamonds. The method of obtaining them, which he describes on hearsay, is similar to that of the celebrated Arabic myth which the travels of Sindbad the sailor and of Marco Polo have made familiar to every one.

The idea of the diamonds being collected by throwing pieces of meat freshly cut from a slaughtered cow or buffalo into a valley inhabited by venomous serpents, which pieces, with diamonds sticking to them, were picked up by birds of prey and recovered from them by the diamond-seekers, probably took its rise from some sacrificial custom in connection with the worship of the sanguinary goddess of riches, whom Heyne ("Tracts," p. 95) alludes to under the name of Ammarwaru, as the partners of the mine. The pieces of meat cut from the victim were probably thrown about over the ground, and were naturally picked up and carried off by the birds. This I believe to have been the foundation upon which the fabulous superstructure was erected.

Beeragurh, or Wairagarh, is, as the crow flies, about 324 miles from Bijapur, northwards, and the distance might therefore have been accomplished in fifteen days. 